\title{
En global fedmeindustri
}

Engelsk oversettelse av hele artikkelen på www.tidsskriftet.no

Da jeg i 2005 startet som doktorgradsstipendiat innen fedme, var ambisjonene store. Norge, og på sikt verden, skulle hjelpes ned i vekt. Så langt har suksessen uteblitt. I verden er 1,46 milliarder voksne personer overvektige (BMI $\left.>25 \mathrm{~kg} / \mathrm{m}^{2}\right)$ og 500 millioner lider av fedme (BMI > 30) (1). Barna rammes også. I Norge ses overvekt eller fedme hos hver femte 8-åring (2). Vektøkningen preger arbeidsplasser, skoler, legekontorer og helseutgifter. Forekomsten av type 2-diabetes, hjerte- og karsykdom, kreft og depresjon øker, for å nevne noen sykdommer.

At fedme er så vanskelig å behandle, vet vi nå har sammenheng med de fysiologiske endringene som følger etter vekttap. Overvektige personer som går ned i vekt, får en reduksjon i sin forbrenning som er større enn forventet ut fra endringen i vekt og kroppssammensetning. I tillegg øker lysten på energirik mat, samtidig som metthetsfølelsen minsker (3). Disse forandringene skjer i et intrikat samspill mellom sentralnervesystemet og perifere signalstoffer som fettvevshormonet leptin, og forklarer at de fleste som går ned i vekt, over tid går opp igjen. Det betyr også at det viktigste midlet mot fedmeepidemien, må bli primær forebygging.

Hovedproblemet er imidlertid ikke fysiologi eller gener, men en konstant tilgang til energirik mat og en effektiv markedsføring som til sammen fremmer et kronisk for høyt energiinntak i forhold til forbruket. Vektøkningen er en normal respons - det gjelder tross alt ganske mange av oss - på et sykt miljø (4). Derfor holder ikke lenger den dårlige løsningen som vi tilbys i dag, nemlig at forebygging av vektøkning stort sett gjøres til et personlig ansvar. Selvsagt kan alle påvirke hva de spiser og hvor mye de beveger seg. Men det er naivt å tro at storparten av befolkningen skal endre levevaner uten at noe gjøres med kilden til problemet. Løsningen må nødvendigvis bli makrotiltak som endrer omgivelsene, slik at det blir lettere å leve et kalorisk velbalansert liv.

Den passive løsningen som er foreslått av koalisjonsregjeringen i England, hvor jeg bor, er såkalt «nudging». Med dette menes små atferdsmodifiserende tiltak som gir befolkningen en «dytt» mot å foreta sunnere valg (5). Eksempler er å plassere grønnsaker nærmere kassen i dagligvareforretninger, servere porsjoner av mindre størrelse og gjøre trapper mer tilgjengelig. Slike tiltak kan ha en viss effekt, og er politisk akseptable siden de ikke forutsetter statlig regulering. Problemet er at slike atferdsmessige «dytt» ikke er nok til å få befolkningen til å endre atferd i tilstrekkelig grad i gunstig retning, blant annet fordi vi påvirkes i gal retning av reklame og andre salgsfremmende virkemidler (5).

Nye reguleringer og lovverk, som blant annet gjør sunn mat billigere og usunn mat dyrere, er nå nødvendig. Reguleringen av tobakksprodukter har utvilsomt gitt bedre helse i befolkningen, og tilsvarende kan helsegevinst trolig oppnås med økt regulering av matprodukter. Noen vil være prinsipielt skeptiske til å regulere hvor og når gitte matprodukter kan selges. Men de fleste er likevel enig $\mathrm{i}$ at vi bør begrense tilgangen til sukkerholdig brus i barneskolen. Videre bør man spørre seg om matindustrien skal kunne reklamere for helseskadelige matvarer samtidig som offentlige myndigheter anbefaler oss å spise mindre av de samme varene. Her har Norge bidratt internasjonalt med et initiativ for å begrense markedsføringen av usunn mat rettet mot barn (6). Danmark har innført avgift på matvarer som inneholder mer enn 2,3\% mettet fett. I Ungarn skattlegges nå mat som er rik på fett, sukker og salt. En strengere regulering av matprodukter er allerede i gang. Spørsmålet er hvor grensene skal settes.

Ansvaret for å utvikle sunnere matvarer, informere bedre om innholdet i matvarer og begrense markedsføringen til utsatte grupper kan ikke overlates til matindustrien. Tobakksindustrien motarbeidet kynisk i flere tiår regulering av sine produkter, og de samme tendensene ses nå hos matindustrien (7). En av strategiene er å hevde at det ikke er tilstrekkelig bevist at en gitt matvare fører til en gitt sykdom. Riktignok kommer trolig ikke den randomiserte studien som viser at én diett fører til færre dødsfall enn en annen. Men vi vet likevel mye om hvilke matvarer som er gunstige for helse og kroppsvekt (8). Vi vet at økt skattlegging av usunne matvarer vil gi en kapital som straks kan brukes på helsefremmende tiltak, som subsidiering av sunne matvarer. Vi vet at slike økonomiske tiltak samt regulering av markedsføring, bedre merking av matvarer, intervensjoner i skolen og økt bevisstgjøring om helsegevinstene av fysisk aktivitet er blant de tiltakene som trolig vil være mest kostnadseffektive og gi raskest uttelling (9). Vi vet nok til å gjøre noe.

\section{Erlend T. Aasheim}

erlend.aasheim@legeforeningen.no

Erlend T. Aasheim (f. 1974) er ph.d., medisinsk redaktør i Tidsskriftet og Academic Clinical Fellow ved Department of Public Health and Primary Care, University of Cambridge.

Ingen oppgitte interessekonflikter.

\section{Litteratur}

1. Finucane MM, Stevens GA, Cowan MJ et al. National, regional, and global trends in body-mass index since 1980: systematic analysis of health examination surveys and epidemiological studies with 960 country-years and 9.1 million participants. Lancet 2011; 377: 557-67.

2. Folkehelseinstituttet. Helsetilstanden i Norge: Overvekt og fedme. www.fhi.no/ artikler/?id=84303 (24.9.2011)

3. Rosenbaum M, Kissileff HR, Mayer LE et al. Energy intake in weight-reduced humans. Brain Res 2010; 1350: 95-102.

4. Swinburn BA, Sacks G, Hall KD et al. The global obesity pandemic: shaped by global drivers and local environments. Lancet 2011; 378: 804-14.

5. Marteau TM, Ogilvie D, Roland $M$ et al. Judging nudging: can nudging improve population health? BMJ 2011; 342: d228.

6. Fikk gjennomslag på global helsekongress: slik vil Norge slanke verden. Verdens Gang 23.5.2010. www vg no/helse/artikkel.php?artid=10007048 (24.9.2011).

7. Brownell KD, Warner KE. The perils of ignoring history: big tobacco played dirty and millions died. How similar is big food? Milbank Q 2009; 87: 259-84.

8. Mozaffarian D, Hao T, Rimm EB et al. Changes in diet and lifestyle and longyerm weight gain in women and men. N Engl J Med 2011; 364: 2392-404.

9. Cecchini M, Sassi F, Lauer JA et al. Tackling of unhealthy diets, physical inactivity, and obesity: health effects and cost-effectiveness. Lancet 2010; 376: 1775-84. 